\title{
Laidun tehokäyttöön emolehmien ja karitsoiden yhteislaidunnuksella
}

\author{
Riitta Sormunen-Cristian, Merja Manninen ja Lauri Jauhiainen \\ MTT, 31600 Jokioinen, sähköpostiosoite: etunimi.sukunimi@mtt.fi
}

\section{Tiivistelmä}

Emolehmien ja karitsoiden yhteislaiduntamista tutkittiin ensimmäistä kertaa Suomessa MTT:n emolehmänavetalla Tohmajärvellä 2003. Tutkimuksessa oli mukana kaksi nauta- ja kaksi nauta-karitsaryhmää. Nautaryhmässä oli kahdeksan hereford (hf)-emoa ja näiden kahdeksan vasikkaa. Nauta-karitsaryhmässä oli hf-nautojen lisäksi 45 suomenlammaspässikaritsaa. Jokaista ryhmää varten varattiin 4,2 ha laidunta. Multaiselle hietamaalle perustettu laidun oli kokeen alkaessa toisen vuoden timotei-nurminata-puna-apilanurmea. Laidunruohon laadun ja maittavuuden parantamiseksi laitumeen kylvettiin toukokuussa 2003 valkoapila-alsikeapila-niittynurmikkaseosta 7,5 kg/ha. Typpeä laitumet saivat kaksi kertaa kesässä, yhteensä 75 kg/ha.

Keväällä 2003 osa emoista oli poikinut vasta pari päivää ennen yhteislaidunnuksen alkua ja tämä näkyi myös emojen aggressiivisena käyttäytymisenä karitsoita kohtaan. Kun emo-vasikkasuhde höltyi ja ryhmät tottuivat toisiinsa, naudat ja karitsat muodostivat yhtenäisen lauman. Seuraavana keväänä tutkimusta toistettaessa emojen ja karitsoiden välillä ei esiintynyt sopeutumisvaikeuksia.

Kesäkuussa kolea sää heikensi nurmen kasvua selvästi. Heinäkuussa nurmen kasvua heikensi puolestaan pitkään jatkunut helle ja kuivuus. Myös alhainen typpilannoitus näkyi nurmen kasvussa.

Laiduntaminen kesti 83 päivää. Nauta-karitsaryhmä söi laitumen tarkempaan kuin nautaryhmä (5 vs. 7-10 cm). Matalaan syöttö ei heikentänyt laitumen jälkikasvua, vaan seuraavan laidunnusjakson alussa satomäärä oli molemmissa ryhmissä lähes aina yhtä suuri. Yhteislaiduntaminen ei vaikuttanut haitallisesti myöskään ruohon laatuun. Puhdistusniittoa ei nauta-karitsalaitumella tarvittu. Lampaat hävittivät erityisesti hevonhierakkaa (Rumex longifolius DC.), joka on laidunnurmen haitallisimpia rikkakasveja. Nautalaitumelta hevonhierakat niitettiin leviämisen estämiseksi.

Nautaryhmän vasikat kasvoivat kesän aikana paremmin kuin vasikat nauta-karitsaryhmässä $(1,26$ vs. $1,08 \mathrm{~kg} / \mathrm{pv} /$ vasikka, $\mathrm{P}<0,001)$. Vaikka ero oli tilastollisesti merkitsevä, sitä voidaan pitää käytännön kannalta vähäisenä. Suurempi laiduntiheys ja karitsoiden mukanaolo ei vaikuttanut emojen kuntoon. Emojen kunto molemmissa ryhmissä oli hyvä kokeen alussa ja lopussa. Karitsat tuottivat lihaa keskimäärin 18,2 kg/eläin. Teurastettaessa karitsat olivat kuluttajan kannalta sopivan rasvaisia. Hyvälaatuisten ruhojen myynti ei tilateurastamolle tuottanut vaikeuksia. Karitsoiden mukaanotto laitumelle lisäsi lihan kokonaistuotosta runsaat $150 \mathrm{~kg} / \mathrm{ha}$.

Puhtaalla, ensi kertaa laidunnettavalla alueella nautojen ja karitsoiden loismäärä oli vähäinen. Kirjallisuuden mukaan yhteislaiduntaminen vähentää loisongelmaa. Tutkimuksessa pidettiin mahdollisena, että emojen läsnäolo suojeli karitsoita villieläimiltä.

Asiasanat: emolehmä, karitsa, karkearehu, lammas, nurmi, yhteislaidun 


\section{Johdanto}

Nautakarja- ja lammastilojen heikko kannattavuus vaatii karkearehujen käytön tehostamista. Yhteislaiduntaminen, jolla tarkoitetaan kahden tai useamman eläinlajin samanaikaista laiduntamista samalla laidunalueella tarjoaa mahdollisuuden edullisen laidunrehun tehokkaampaan käyttöön. Eri eläinlajit laiduntavat eri tavalla. Lammas syö naudasta poiketen myös lantakasojen ympäriltä (Brelin, ref. Abaye ym. 1994) sekä käyttää ravinnokseen useita rikkakasveja (Van Keuren, ref. Abaye ym. 1994). Yhteislaiduntamisessa laidun kuluu tasaisesti, minkä seurauksena hylkylaikkujen ja täten myös puhdistusniittojen, työn ja konetallauksen määrä vähenevät. Lampailla ja naudoilla ei ole samoja sisäloisia, joten yhteislaiduntaminen vähentää myös loisongelmaa (Nolan \& Connolly 1989, 1990). Huolimatta lupaavista ulkomaisista tuloksista, yhteislaiduntamista ei aikaisemmin ole Suomessa tutkittu. Tutkimuksen tarkoituksena oli selvittää emolehmien ja karitsoiden yhteislaiduntamisen vaikutusta laitumen tuottoon, kasvuston laatuun ja nautojen ja lampaiden painonlisäyksiin ja loisiin. Yhteislaiduntamista tutkittiin kahtena kesänä 2003-2004. Tässä kirjoituksessa käsitellään kesän 2003 tuloksia.

\section{Aineisto ja menetelmät}

Tutkimus toteutettiin Makeran osittain rahoittamassa "Laatulihaa tehokkaalla emolehmätuotannolla" hankkeessa MTT:n emolehmänavetalla Tohmajärvellä. Multaiselle hietamaalle aidattu laidunalue oli toisen vuoden timotei (Iki 65 \%)-nurminata (Antti 30 \%)-puna-apilanurmea (Bjursele 5 \%). Kasvuston laadun ja maittavuuden parantamiseksi laitumeen kylvettiin toukokuussa valkoapila (Jögeva-4 33 \%)alsikeapila (Frida 27 \%)-niittynurmikkaseosta (Balin 40 \%) 7,5 kg/ha. Laitumet saivat typpeä $75 \mathrm{~kg} / \mathrm{ha}$ kahtena eränä (15.5. ja 4.-15.7.). Koska alkukesän laidunnurmi yleensä kasvaa nopeammin kuin mitä eläimet ennättävät syödä, tehtiin puolet laidunalasta säilörehuksi juhannuksen molemmin puolin.

Tutkimuksessa oli kaksi nauta- ja kaksi nauta-karitsaryhmää. Nautaryhmässä oli kahdeksan hereford (hf)-emoa ja näiden kahdeksan vasikkaa sekä nauta-karitsaryhmässä hf-nautojen lisäksi 45 suomenlammaspässikaritsaa. Emojen astuttamista varten jokaisessa ryhmässä oli myös yksi sonni. Emot ja vasikat olivat MTT:n omasta karjasta. Karitsat ostettiin Vaalasta, Pelson vankilasta. Laidunkauden alkaessa karitsat olivat 81 päivän ikäisiä ja painoivat keskimäärin 28,9 kg. Vasikat olivat syntyneet maalis-toukokuussa (21.3. - 30.5.2003) ja niiden paino kesäkuun alussa oli keskimäärin 89 kg. Jokaista ryhmää varten varattiin 4,2 ha laidunta jaettuna kolmeen syöttökaistaan. Edellyttäen, että yksi nautayksikkö (ny) on 500 elopainokiloa, niin kokeen alussa nautaryhmän laidunpaine oli 3,26 ny/ha ja nauta-karitsaryhmän 3,88 ny/ha. Laidunnusjaksoja oli viisi ja laidunkauden (3.6.-26.8.) kokonaispituus 83 päivää. Eläimet punnittiin kokeen alussa ja lopussa sekä kokeen aikana kuukauden välein. Emot kuntoluokitettiin (Lowman ym. 1976) punnitusten yhteydessä. Loislääkitystä eläimille ei annettu.

Laitumen sato määritettiin ja ruohon korkeus mitattiin jokaiselta syöttökaistalta ennen ja jälkeen laiduntamisen. Ruohon kemiallinen koostumus ja rehuarvo määritettiin ennen laiduntamista. Kasvilajikoostumus tehtiin kesä- ja elokuussa. Naudoilta ja karitsoilta otettiin sonta- ja papananäytteet kokeen alussa ja lopussa ja laidunnuksen aikana kerran kuukaudessa. Loismääritystulokset raportoidaan myöhemmin.

Aineisto analysoitiin lineaarisilla sekamalleilla käyttäen SAS/MIXED-proseduuria. Valituissa malleissa koeyksikkönä pidettiin koeruutua, johon käsittelyt oli kohdistettu. Samassa ruudussa olleiden eläinten tulosten korreloituminen huomioitiin (Morris 1999).

\section{Tulokset ja tulosten tarkastelu \\ Sääolot}

Kesäkuu oli kolea ja heinäkuu kuiva ja helteinen. Kesä-, heinä- ja elokuun keskilämpötilat olivat 10,9, 19,5 ja $14,1^{\circ} \mathrm{C}$. Vastaavan ajan kokonaissademäärä oli $188 \mathrm{~mm}$.

\section{Laidun}

Kesäkuun alussa laitumen keskimääräinen kasvilajikoostumus oli 42 \% timoteita, 23 \% nurminataa ja 18 \% puna-apilaa kuiva-aineessa. Valkoapilan määrä oli vähäinen. Ruohon alkukorkeus oli sopivan mittaista naudoille. Lampaille sopivana korkeutena pidetään alle $10 \mathrm{~cm}$ tasaisen ja tiheän nurmen alueilla (Hodgson 1990). Laitumen tarjolla oleva sato oli yhtä suuri molemmissa eläinryhmissä (Taulukko). Ennen laiduntamista nautaryhmän kuiva-ainesadot vaihtelivat välillä 1025-2455 kg/ha ja nauta- 
karitsaryhmän 939-2703 kg/ha. Kun syötettyjen laidunkaistojen, samoin kuin säilörehuksi tehdyn alueen kasvuunlähtö oli kuivuuden takia heikkoa, laidunrehua oli ajoittain niukasti. Heinäkuussa nautaryhmä sai lisärehuksi kuivaa heinää 1085 kg ja nauta-karitsaryhmä 2185 kg kuiva-aineena.

Nauta-karitsaryhmä söi laitumen tarkempaan ja lyhempään sänkeen kuin nautaryhmä (korkeus syötön jälkeen 5 vs. 7-10 cm). Matalaan syöttö ei heikentänyt laitumen jälkikasvua, vaan seuraavan laidunnusjakson alussa satomäärä oli molemmissa ryhmissä lähes aina yhtä suuri. Yhteislaiduntaminen ei vaikuttanut haitallisesti myöskään ruohon laatuun. Laidunruohon energia- ja valkuaisarvot olivat keskimäärin 1,1 RY/kg ka ja 91 g ohutsuolessa imeytyvää valkuaista (OIV)/kg ka. Raakavalkuaista oli keskimäärin 203 g/kg ka ja neutraalidetergenttikuitua (NDF) 460 g/kg ka.

Nautanurmen rikkakasvipitoisuus nousi kesän aikana $10 \%$ :sta 28 \%:iin kuiva-aineessa. Yhteislaitumella rikkakasveja oli syksyllä vain $10 \%:$ ia. Rikkakasvienemmistön muodosti hevonhierakka (Rumex longifolius DC.), jota tavattiin peräti 0,40 yksilöä neliömetrillä. Hevonhierakka on laidunnurmien haitallisimpia rikkakasveja. Yksi hevonhierakkayksilö voi tuottaa jopa 9000 siementä. Puhdistusniittoa yhteislaitumella ei tarvittu, sillä lampaat tuhosivat selvästi laitumen rikkakasvustoa, erityisesti hevonhierakkaa. Nautalaitumet joudutttin hevonhierakan leviämisen ja hylkylaikkujen takia puhdistusniittämään.

\section{Eläintulokset}

Osa emoista oli poikinut vain pari päivää ennen laidunkauden alkua. Ilmeisesti juuri vastapoikineet emot kummeksuivat karitsoita eivätkä tienneet, kuinka niihin olisi pitänyt suhtautua. Kun nauta- ja karitsalaumat joutuivat liian lähelle toisiaan, emot reagoivat aggressiivisesti karitsoita kohtaan. Tilanteen rauhoittamiseksi laumat eristettiin lyhyeksi aikaa sähköaidalla. Kun emo-vasikkasuhde höltyi ja ryhmät tottuivat toisiinsa, naudat ja karitsat muodostivat yhtenäisen lauman.

Kesäkuun alusta heinäkuun loppuun emojen ja vasikoiden painomuutokset olivat molemmissa ryhmissä yhtä suuret. Painoeroja syntyi elokuussa. Nautaryhmän vasikat kasvoivat kesän aikana keskimäärin 15 kg paremmin kuin vasikat nauta-karitsaryhmässä (päiväkasvu 1,26 vs. 1,09 kg/vasikka, $\mathrm{P}<0,001)$. Vaikka ero päiväkasvuissa oli tilastollisesti merkitsevä, sitä pidettiin käytännön kannalta vähäisenä. Nauta- ja nauta-karitsaryhmissä emojen painon lisäys oli 52,8 ja 27,8 kg. Suurempi laiduntiheys ja karitsoiden mukanaolo ei vaikuttanut emojen kuntoon. Emojen kunto oli molemmissa ryhmissä hyvä kokeen alussa ja lopussa.

Ultraäänimittausten perusteella karitsat olivat ennen teurastusta kuluttajan kannalta sopivan rasvaisia. Kokeen alusta kokeen loppuun karitsoiden painonlisäys oli keskimäärin 15,6 kg/karitsa (188 g/karitsa/pv). Karitsoiden loppupaino oli keskimäärin 44,5 kg ja lihatuotos 18,2 kg/eläin. Jos alkukasvatuskauden teurasprosentiksi arvioidaan 40, niin 1550 kilon kokonaislihatuotoksesta karitsat tuottivat laitumella 600 kiloa. Karitsat teurastettiin kahdessa erässä (28.8. ja 2.9.) Heikkilän tilateurastamossa Kontiolahden Varparannalla. Hyvälaatuisten ruhojen myynti ei tilateurastamolle tuottanut vaikeuksia.

Kun kasvutuloksia tarkastellaan laidunhehtaaria kohden, laitumen käytön tehostuminen tulee esille selvimmin kuin eläinkohtaisten lukujen perusteella. Karitsoiden mukaanotto laitumelle lisäsi lihan kokonaistuotosta runsaat $150 \mathrm{~kg} / \mathrm{ha}$. Lisäys saatiin karitsoiden kasvun kautta, sillä yhteislaidunvasikoiden kasvu jäi noin 30 kg/ha heikommaksi kuin vasikoiden kasvu pelkällä nautalaitumella.

Puhtaalla, ensi kertaa laidunnettavalla alueella nautojen ja karitsoiden loismäärä oli vähäinen. Kirjallisuuden mukaan lampaiden ja nautojen loismäärä on yhteislaidunnuksessa pienempi, kuin jos molemmat lajit laiduntaisivat yksinään (Nolan \& Connolly 1990). Etenkin lampaiden on sanottu hyötyvän yhteislaiduntamisesta yksinlaiduntamiseen verrattuna.

Pian laidunkokeen loppumisen jälkeen lehdissä alkoi olla tietoja susien tappamista kotieläimistä Tohmajärvellä. Susien jälkiä nähtiin myös emolehmänavetan ulkotarhoissa. Laitumella susia ei kesän aikana havaittu, mutta on mahdollista, että sudet kävivät jo elokuun öinä katsastamassa karitsoita aidan takaa. Emojen suojeluksessa karitsoiden hallitsematonta teurastusta ei kuitenkaan päässyt tapahtumaan. 
Taulukko. Laidun- ja eläintuloksia.

\begin{tabular}{|c|c|c|c|c|}
\hline & $\begin{array}{l}\text { Naudat } \\
\text { yksin }\end{array}$ & $\begin{array}{l}\text { Naudat } \\
\text { ja karitsat }\end{array}$ & SEM $^{1}$ & Merkitsevyys $^{2}$ \\
\hline Ruohon alkukorkeus 3.6., cm & 25 & 26 & 4,3 & \\
\hline Ruohon loppukorkeus 26.8., cm & 10 & 5 & 0,4 & \\
\hline Satoa tarjolla 3.6., kg ka/ha & 2455 & 2703 & 410 & \\
\hline Satoa tarjolla 7.7., kg ka/ha & 1052 & 939 & 312 & \\
\hline Satoa tarjolla 29.7., kg ka/ha & 1278 & 1249 & 235 & \\
\hline Satoa tarjolla 20.8., kg ka/ha & 1025 & 1003 & 55 & \\
\hline Emojen alkupaino 3.6., kg & 672 & 676 & 31,7 & \\
\hline Emojen loppupaino 26.8., kg & 725 & 704 & 31,7 & \\
\hline Emojen kunto $^{3} 3.6$. & 3,5 & 3,3 & 0,15 & \\
\hline Emojen kunto 26.8 . & 3,5 & 3,4 & 0,15 & \\
\hline Vasikoiden alkupaino 3.6., kg & 91 & 89 & 6,2 & \\
\hline Vasikoiden loppupaino 26.8., kg & 196 & 179 & 6,2 & \\
\hline
\end{tabular}

${ }^{1}$ Keskiarvon keskivirhe. ${ }^{2} * \mathrm{P}<0,05$; ** $\mathrm{P}<0,01$; ***P<0,001. ${ }^{3}$ Asteikko 0-5 (0=laiha, 5=lihava).

\section{Johtopäätökset}

Karitsoiden ja emolehmien yhteislaiduntaminen näyttää lupaavalta, mikäli eläinpaine laitumen tuottoon nähden voidaan pitää sopivana. Tässä tutkimuksessa laitumen rehupula heikensi sekä nautojen että karitsoiden kasvua elokuussa. Vastapoikineet emot ja karitsat vaativat totuttautumista toisiinsa ennen yhteislaiduntamista.

\section{Kirjallisuus}

Abaye, A.O., Allen, V.G \& Fontenot, J.P. 1994. Influence of grazing cattle and sheep together and separately on animal performance and forage quality. J. Anim. Sci. 72: 1013-1022.

Hodgson, J. 1990. Grazing Manament. Science into Practice. Longman Handbooks in Agriculture. New York. 203 p.

Lowman, B.G., Scott, N.A. \& Sommerville, S.H. 1976. Condition Scoring of Cattle. The East of Scotland College of Agriculture. Animal Production, Advisory and Development Department. Bulletin No. 6. 31 p.

Morris, T.R. 1999. Experimental Design and Analysis in Animal Sciences. CABI Publishing, Wellingford, UK. 208 p.

Nolan, T. \& Connolly, J. 1989. Mixed vs. monograzing by steers and sheep. Anim. Prod. 48: 519-533.

Nolan, T. \& Connolly, J. 1990. Effect of mixed grazing on establishment and maintenance of clover in a sown ryegrass with white clover sward. Soil grassland relationships. In: Proceedings $13^{\text {th }}$ General Meeting of the European Grassland Federation. Bansk Bystrica,Czechoslowakia, 25-29 June, p. 134. 